\title{
Simultaneous Events, Parallel Themes, Spatial Oppositions: A Comparative Content Analysis of Traditional Dance ${ }^{1}$
}

\author{
JÁNOS FÜGEDI \\ Institute for Musicology \\ Research Centre for the Humanities \\ Táncsics Mihály u. 7., H-1014 Budapest, Hungary \\ Email: fugedi.janos@btk.mta.hu
}

Received: October 2018; accepted: January 2019

\begin{abstract}
This paper focuses on the smallest units and micro-structures of traditional dance. I propose a new approach that ventures beyond the identification of simple syntagmatic relations derived from the temporal succession of movements: a former practice of dance analyses that relied on theories borrowed from linguistics and music. The following discussion, based on the analysis of movement content as spatial change, demonstrates the existence of independent but simultaneous movement events in dance: each event possesses an expressive potential and the capacity for performance as a single rhythmical unit. Identifying events creates the possibility of separating parallel running, autonomous movement themes. Amongst the examined structures, an exceptional one, here termed contrakinesis, emerges, which represents spatial opposition as a recurring, characteristic phenomenon in East Central European traditional dance. The theory of simultaneous events and parallel themes reveals that concepts of expression in traditional dance can be comprehensively recognized only through a content-oriented exploration relying on movement analysis: an approach derived from investigating the dance itself.
\end{abstract}

Keywords: traditional dance, dance analysis, content analysis, contrakinesis, movement event, movement theme, movement interpretation

\section{Introduction}

In form analyses of traditional dance, researchers have directed their attention largely towards two of three integral characteristics of dance movements: space and time. The third, dynamics, has rarely formed the focus of investigation in

1. This research was supported by a scholarship from the Hungarian National Research, Development, and Innovation Office NKFIH (project no. K 124270). 
this field, supposedly due to a lack of elaborated means. ${ }^{2}$ From a summary of European research by Anca Giurchescu and Eva Kröschlova, it can be concluded that the majority of the literature primarily discusses semantics in relation to motifs, considered as the "smallest significant form unit," 3 and the processes through which larger and more complex units are constructed. Through the process of decomposition of motifs, distinctive elements smaller than these units have been identified. While formulating analytical concepts, several authors have emulated musicological or linguistic theories to establish the elemental or higher-level units of dance. ${ }^{4}$

This study focuses on the smallest movement units of dance and small structures which have so far received comparatively little scrutiny. This investigation is focused on the content of movements. ${ }^{5}$ Content is understood here as interpreted spatial manifestation of change in accordance with Rudolf Laban's view: ${ }^{6}$ spatial dislocations of the body and its parts are considered the determinative factors of movement expression. This appears appropriate for application to European traditional dance. The interpretive approach utilized in this study is situated between analyses of the space-time-dynamics attribute trinity of movements, and those concerned with their meaning in relation to cognition and semantics. ${ }^{7}$

2. The research lead by Judy van Zile (reported by Bartenieff et al.) and Csilla Könczei's investigations represent rare exceptions. To record dynamics and quality of movement, Van Zile's research team applied the Laban Movement Analysis based on Laban's Effort Theory to a southwest Indian classical dance; see Irmgard BARTENIEFF et al., "The Potential of Movement Analysis as a Research Tool: A Preliminary Analysis," Dance Research Journal 16/1 (Spring 1984), 3-26; Rudolf LABAN and F. C. LAWRENCE, Effort (London: Macdonald and Evans, 1947). The semiotics-influenced investigations by Könczei pointed out corresponding spatial and dynamic transformation rules of contrasting performances in a ritual dance. See Csilla KÖNCZEI, "Principles of Creation in the Borica Dance," in ead., Táncelméleti írások/Writings in Dance Theory (Cluj: Editura Fundaţiei pentru Studii Europene, 2007), 117-118. This paper was originally published in 1989, in Hungarian.

3. Anca GIURCHESCU and Eva KRÖSCHLOVA, "Theory and Method of Dance Form Analysis," in Dance Structures: Perspectives on the Analysis of Human Movement, ed. by Adrienne L. KAEPLER and Elsie Ivancich DUNIN (Budapest: Akadémiai Kiadó, 2007), 28 (= Studies in Ethnology, vol. 3).

4. European and American methods are discussed below.

5. György Martin understood “content” as "meaning," while Lujza Ratkó interpreted it as “a traditional principle formulated in the symbolic language of movements." Roselyn Stone's approach appears to be related to the understanding discussed in this paper; she regards "content" and "recognized relatedness" similarly. See György MARTIN, "A néptáncok elemzése és rendszerezése" [Analysis and classification of folk dances], in Népzene, néptánc, népi játék, ed. by Mihály HOPPÁL (Budapest: Akadémiai Kiadó, 1990), 190; Lujza RATKÓ, "A néptánc tartalmi elemzése" [Content analysis of traditional dance], in A nyíregyházi Jósa András Múzeum Évkönyve, ed. by Péter NÉMETH (Nyíregyháza: Jósa András Múzeum, 2002), 259; Roselyn E. STONE, "Human Movement Forms as Meaning-Structures: Prolegomenon," The Quest 23 (1975), 10.

6. Rudolf LABAN, Choreographie (Jena: Eugen Dietrich, 1926), 3.

7. In the $1970 \mathrm{~s}$, several researchers investigated the subject of the meaning of human movement - only two are mentioned here. In the field of dance, Valéria Dienes approached symbolics, the spiritual dimension, through the meaning of movement formulated by physical factors of space, time, and dynamics. See Valéria DIENES, “A szimbolika föbb problémái” [The main problems of symbolics], Táncmüvészeti Értesitö 1 (1974), 63-69. From her semasiological point of view, Drid Williams regarded the human movement as a structured system of meanings. See Drid WILLIAMS, "Human Action Sign and Semasiology," in Dance Research Collage: A Variety of Subjects Embracing the Abstract and the Practical, ed. by Patricia A. ROWE and Ernestine STODELLE (New York: Congress on Research in Dance, 1979), 39. 
In contrast to applying musicological or linguistic concepts to the field of dance research, this paper offers an approach relying on movement analysis. Following a detailed investigation into the complexity of the smallest expressive units of traditional dance, I discuss the synchronous features of content and the diachronic use of units. The conclusion challenges the general viability of linguistics-based models in dance analysis, aiming to demonstrate the necessity for a comprehensive investigation into the compositional practice of motifs and dance.

Within the wide range of traditional dance representations, the present investigation focuses on selections from the repertoires of East Central Europe. A further limitation is that most of the examples are sections, motifs, and movements found in Hungarian dance, although samples are also taken from the notation literature of neighboring nations. This analysis focuses on solo performances and leg movements - supports and gestures - in accordance with their primary use in most European traditional dance to express content.

\section{Concepts of the Smallest Units of Dance}

A common practice of traditional dance analysis is to establish the smallest units by dividing the flow of movements sequentially by the rhythm of movement types. This clear approach facilitates identifying entities, however, the actual movement content and the understanding of these units can only be gleaned indirectly from the texts. Although the following introduction to theoretical frameworks may appear comparatively extensive, this is necessary to identify often overlooked concepts.

Olga Szentpál states that Béla Bartók and Zoltán Kodály’s folk song analysis aided the development of her method. ${ }^{8}$ In her paper - one of the earliest structural analyses in the field of traditional dance - she declares the "movement" and the "pause" as "basic elements" of dance. She lists the most frequent movement types of Hungarian and European traditional dance, which are, according to her, the step, spring, running, turning, circling, gestures, and movements of the supporting leg (such as rotation and change of the vertical level of the body: movements without changing location). ${ }^{9}$

8. Olga SZENTPÁL, "Versuch einer Formanalyse der Ungarischen Volkstänze," Acta Ethnographica Academiae Scientiarum Hungaricae 7/3-4 (1958), 259. She did not mention specifically, how and in which respect.

9. In the 1930s and 1940s, Olga Szentpál, in collaboration with her husband, art historian Máriusz Rabinovszky, developed a highly elaborated dance analysis and system of pedagogy, called the taxonomy (or doctrine) of the Szentpál School. They were the first in Hungary to introduce the use of Laban kinetography as a research tool and educational framework. The exercises of Szentpál's taxonomy and training were notated in great detail, but remain unpublished until today. For further discussion of this topic, see János FÜGEDI and Lívia FUCHS, "Doctrines and Laban Kinetography in a Hungarian Modern Dance School in the 1930s," Journal of Movement Arts Literacy 3/1 (2016), 1-26. 
The initial stage in Szentpál's approach to dance analysis is to define the "smallest structural units:" the motifs. ${ }^{10}$ She states that "[w]e consider a motif to have two, three, or more members according to the number of consecutive movements it contains." 11 She defines neither the term "member" (gliedrig) nor "movement" (Bewegung) in further detail, but provides examples: Figures 1-2 have two members, Figures 3-4 three, Figures 5-6 four, Figure 7 five, and so forth. ${ }^{12}$ (For an index and description of the figures, see Table 1.) Apparently, she uses the terms "member" and "movement" synonymously. Note that in her examples, several beats include simultaneous supporting and gesturing movements of the legs. ${ }^{13}$

Discussing the structure of Hungarian traditional dance, György Martin and Ernő Pesovár outline their approach "in the spirit of the principles deduced from folklore research."14 They add that "many analogies have been drawn, renewed incentives have sprung, and valuable experience has been gained particularly from ethnomusicology and linguistics." They name the smallest unit of dance "kinetic element," and state that

the kinetic element is a phenomenon essentially analogous to the smallest indivisible linguistic unit, the speech sound. The speech sound (phoneme) cannot be divided into smaller independent units, yet the phases of articulation can be analyzed. ${ }^{15}$

10. SZENTPÁL, "Versuch," 265.

11. "Zwei-, drei- oder mehrgliedrig nennen wir das Motiv nach der Anzahl der in ihm enthaltenen, einander folgenden Bewegungen." Ibid., 265.

12. For the sake of readability, all kinetographic notation examples from different sources are re-edited with the LabanGraph application. See János FÜGEDI, "LabanGraph: A Computer Editor for the Laban System of Notation," in Proceedings of the Thirtieth Biennial Conference of the International Council of Kinetography Laban, ed. by Marion BASTIEN, Thomas Townsend BROWN and János FÜGEDI (s.1.: International Council of Kinetography Laban, 2019), 173-183. To follow the change of orthography since the cited papers were published, new symbol usages replace old ones according to the contemporary versions of kinetography as proposed by Albrecht Knust and Ann Hutchinson Guest. See Albrecht KNUST, Dictionary of Kinetography Laban, 2 vols (Plymouth: Macdonald and Evans, 1979); Ann HUTCHINSON GUEST, Labanotation: The System of Analyzing and Recording Movement (London: Routledge, 2005). For easier recognition, the notation of contacting gestures follows the recommendations by János Fügedi and Gábor Misi. See János FÜGEDI and Gábor MISI, "Ways of Notating Floor Touching Gestures with the Foot," in Proceedings of the Twenty-Sixth Biennial Conference of the International Council of Kinetography Laban (s.1.: International Council of Kinetography Laban, 2009), 43-60. None of the adjustments change the movement contents published originally.

13. The first beat of Figure 1, the first and second beats of Figure 3, the second beat of Figure 4, the first and second beats of Figure 5, the third and fourth beats of Figure 6, the third beat of measure 1 and the first beat of measure 2 of Figure 7.

14. György MARTIN and Ernő PESOVÁR, "A Structural Analysis of the Hungarian Folk Dance: A Methodological Sketch," Acta Ethnographica Academiae Scientiarum Hungaricae 10/1-2 (1961), 3.

15. Ibid., 4. 


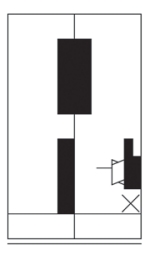

FIG. I

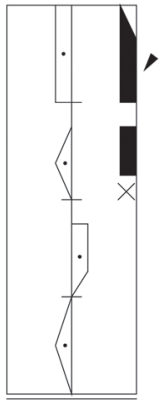

FIG. 6

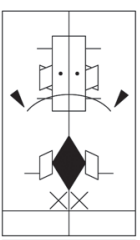

FIG. 2

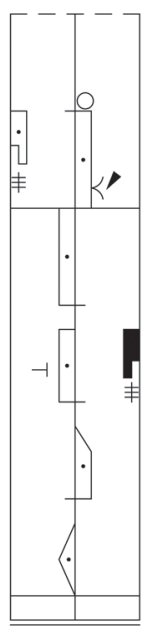

FIG. 7

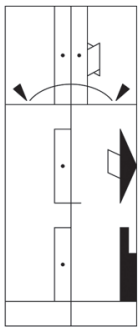

FIG. 3

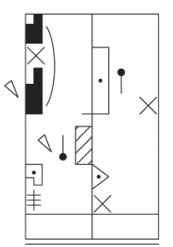

FIG. 8

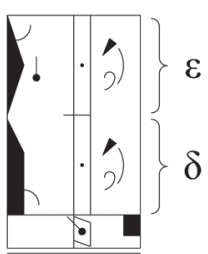

FIG. 9

FIG. 4

FIG. 5

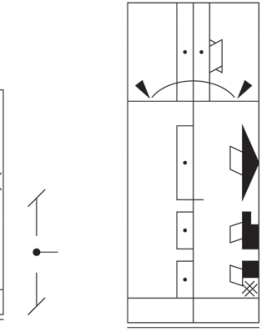

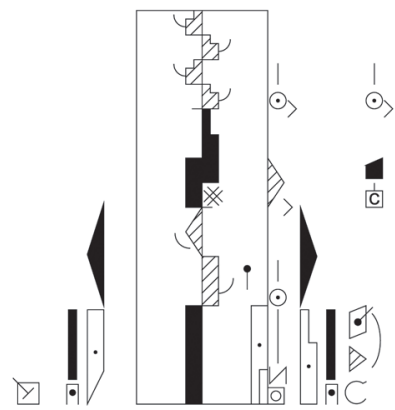

FIG. IO 
According to their understanding, the kinetic element

is performed during the smallest time unit of the dance. The kinetic element is not a closed unit in itself yet never consists of more than one member. Thus it is not an organic unit morphologically. ${ }^{16}$

They explain that the motif in Figure 8

consists of three kinetic elements: 1. the right leg jumps sideways while the lower part of the left leg (the shank) swings backwards; 2. the left foot steps forward; 3. the right leg jumps backwards while the left leg swings forwards. ${ }^{17}$

Though they consider the kinetic element indivisible into further independent units, they acknowledge the possibility of its division into "phases." The definition of "phase" is absent, however, it can be approximately deduced from the following citation:

The third kinetic element of the above motive consists of the following phases:

a) jump from the left foot, $b$ ) both legs in air, $c$ ) right foot touches ground and

d) bends a little while left leg swings forward and $e$ ) bends a little. ${ }^{18}$

Akin to Szentpál, demonstrated for example in Figures 1 and 3-7, Martin and Pesovár regard the simultaneous support and gesture of the legs as a single kinetic element. Martin retained this view of compound units in his later works, for instance in his monographs on the motifs of the Sárköz-Danube region, ${ }^{19}$ and in his individual-centered research of legényes. ${ }^{20}$

In their paper, Anca Giurchescu and Eva Kröschlova refer to ethnomusicology and ethnolinguistics, ${ }^{21}$ both of which have influenced the development of dance research methodology, ${ }^{22}$ but they also declare that ethnochoreology has pursued

16. Ibid., 5 .

17. Their textual description does not exactly match the kinetographic notation in their paper. Figure 8 corresponds to Martin and Pesovár's motif no. 3, which can be found in dance no. 1 which they published. See ibid., 28.

18. Ibid., 4.

19. György MARTIN, Motívumkutatás, motívumrendszerezés: A sárközi-dunamenti táncok motívumkincse [Motif research, motif classification: The motif repertoire of the dances from the Sárköz and Danube region] (Budapest: Népmüvelési Intézet, 1964).

20. Zsigmond KARSAI and György MARTIN, Lörincréve táncélete és táncai [Dance life and dances in Lőrincréve] (Budapest: MTA Zenetudományi Intézet, 1989); György MARTIN, Mátyás István 'Mundruc': Egy kalotaszegi táncos egyéniségvizsgálata [István Mátyás 'Mundruc': An individual-centered investigation of a Kalotaszeg dancer] (Budapest: Planétás, 2004).

21. GIURCHESCU and KRÖSCHLOVA, "Theory," 25.

22. No reference or further explanation of this statement was provided. 
its own path. ${ }^{23}$ They name the smallest structural entity "motif-element," and state that it cannot be decomposed further. However - as they explain later in the paper it can be analyzed as simultaneous movements: "The content of a motif-element is not necessarily a simple movement, but it may be a combination of more than one kinetic element, all together performed simultaneously in one beat." ${ }^{24}$ Examples of the "kinetic element" are provided textually, such as step, hop, swing, turn, leap, stamp, clap, as well as various gestures (analytically, each may be considered a complex movement). However, there is no attempt to provide an example, either notated or textually described, illustrating the idea of the motif-element (similarly to the lack of clarification regarding all other higher structural concepts). It can be inferred only through an included analysis of a Czech couple dance, roveřačka, that the two beats of a motif-cell in Figure 9 (identified in the paper as c') consist of two motif-elements, $\delta$ and $\varepsilon .^{25}$ The authors also state that a motif-element can be "mono-kinetic," comprising a single kinetic element, or it can be a complex "poly-kinetic" component. They do not provide a definition of the "poly-kinetic" element (nor an explanation of the "kinetic element,"); it remains ambiguous whether "motif-elements" $\delta$ and $\varepsilon$ are "mono-kinetic" or "poly-kinetic."

Separately from developments within European structural analysis of traditional dance, approximately a decade later Adrienne Kaepler presented an analytical method directly related to modern linguistics. ${ }^{26}$ Akin to Martin and Pesovár's earlier research, ${ }^{27}$ she regards the structural linguistic concepts phonemes and morphemes as patterns of components found in dance; she uses the analogous terms "kinemes" and "morphokines," similarly to Ray Birdwhistell in the 1950s. ${ }^{28}$ (She equated kineme with the motif-element and morphokine to the motif-cell when she republished her original analytical concept, unchanged in essence, but enriched with kinetographic notations). ${ }^{29}$ Kaepler states: "Kinemes are those ac-

23. Grażyna Dabrowska and Kurt Petermann's paper addressing the same subject is not mentioned here because its content is reflected in the paper cited above, GIURCHESCU and KRÖSCHLOVA, "Theory." See Grażyna DABROWSKA and Kurt PETERMANN, "Grundlagen der Struktur- und Formanalyse des Volkstanzes," in Analyse und Klassifikation von Volkstänzen, ed. by eid. (Krakow: Polskie Wydawnictwo Muzyczen, 1983), 9-31.

24. GIURCHESCU and KRÖSCHLOVA, "Theory," 29.

25. Ibid., 42-43. Direct correspondence of notation and the element identification is only added here, as deducted from the paper.

26. Adrienne L. KAEPLER, "Method and Theory in Analyzing Dance Structure with an Analysis of Tongan Dance," Ethnomusicology 16/2 (May 1972), 215. She identified her theoretical background as "post-Bloomfieldean linguistics."

27. MARTIN and PESOVÁR, "A Structural Analysis," 4.

28. The terms "allokine," "kineme," and "kinemorph" were introduced by Ray Birdwhistell in his early report on presenting possible new directions of interpreting human movements as structural units that correspond morphologically to concepts of allophone, phoneme, and morpheme established in late nineteenth- and early twentieth-century linguistics. See Ray L. BIRDWHISTELL, Introduction to Kinesics: An Annotation System for Analysis of Body Motion and Gesture (Washington, D.C.: Department of Foreign Service Institute, 1952 ), 22.

29. Adrienne L. KAEPLER, "Method and Theory in Analyzing Dance Structure with an Analysis of Tongan Dance," in KAEPLER and DUNIN (eds.), Dance Structures, 53. 
tions and positions which, although having no meaning in themselves, are the basic units from which all dance of a given tradition is built." 30

According to Kaepler's examples, $\mathrm{L}_{1}$ kineme represents a step forward; $\mathrm{L}_{4 \mathrm{~d}}$ depicts a jump with both feet forward from a closed to an open position at a low level. ${ }^{31}$ Identifying a kineme (in actuality, a block of complex movements) as the smallest unit of dance led to Kaepler's statement that "[a]fter the inventory of kinemes has been delineated we can analyze how they are combined to form larger units." 32

Drid Williams's theoretical investigation of deep structures of dance raises the problem of comparing linguistic and dance structures:

An important feature of the contrast between some of the structural elements inherent in spoken language and semasiological gesture language is that of formal logical space, which is one-dimensional, and three-dimensional space, which forms the basis for dance or ritual semiotics. ${ }^{33}$

Williams addresses this dilemma by asserting the validity of transforming three-dimensional relations into one-dimensional binary opposition. She later tackles the question of units, synchrony, and diachrony, defining two zones of temporal aspects: the synchronic relations, which usually do not constitute immediately receivable systems of actions, and the diachronic "unfolding" of action events and utterances as systems that are apperceived by observers. ${ }^{34}$ She presents an example analysis of a notated section from the ballet Swan Lake, ${ }^{35}$ reproduced here in Figure $10 .{ }^{36}$ Williams describes the first beat in detail as a group of syn-

30. KAEPLER, "Method (1972)," 174. The unambiguous definition of both "meaning" and "position" is missing. "Meaning" is bound to be "understood as movements" by dancers (see ibid., 185), while a kineme (such as a step forward, L1) is not. The term "position" appears several times in the text, but in different contexts: as the identification of a double support; a reference to kneeling or sitting; the positions of the fingers; the positions of the arm, or as an element of morphokines, a kineme itself (ibid., 178-185). In this respect, the question arises how a position can be referred to as a kineme when the meaning of the word kineme is a unit of movement, while a position is generally understood as a state of body constellation; in other words, non-movement.

31. Ibid., 178. In the absence of a movement analytical framework, none of the terms "forward," "closed," and "open" position, and "low level" can be understood clearly, only in a general sense. The terms resemble those of Kinetography Laban (or Labanotation), but - as discussed in footnote 56 - Kaepler understands the movement reference differently compared to the aforementioned dance notation system.

32. Ibid., 176.

33. Drid WILLIAMS, "Deep Structures of the Dance 2: Constituent Syntagmatic Analysis," Journal of Human Movement Studies 2/3 (1976), 171.

34. WILLIAMS, "Human Action Sign," 50.

35. Williams did not indicate the source of the notation. The same two measures (with an added third) were published in Nelson Goodman's Languages of Art. Of its several editions and reprintings, see, for example, Nelson GOODMAN, Languages of Art (Indianapolis: Hacket Publishing Company, 1981), 125. The notation stems from the Archives of Notated Theatrical Dances of the Dance Notation Bureau, New York.

36. The whole or a section of the notation on page 46 of Williams's "Human Action Sign" is repeated on pages 50, 52, and 53: each differing from page 46. The repetitions sometimes include nonsense indications, such as front signs instead of the palm surface, white pins instead of front signs, the sign of the head instead of the indication of back to normal. Figure 10 here presents a reproduction of the notation on page 46, which seems correct from the viewpoint of Labanotation orthography. 
chronic transformations. ${ }^{37}$ The complexity of changes on this specific beat she regards as a single "kineseme," one "action sign," including one or two kinemes, supposedly those by the arms and the head.

A common feature of the aforementioned analytical approaches is the theoretical influence of linguistics and musicology. European methodologies perceived the motif as the "smallest" or "organic" unit of dance, sequentially decomposing motifs to diachronic elements. The American approaches identified their units through linguistic terms such as "kineme" or "kineseme." Similarly to the series of speech sounds in language, the action sign system was regarded as a series of gross physical movements. It is notable that no underlying movement analysis system was identified as the basis for communicating, interpreting, and understanding the subjects in any of the analyses cited. ${ }^{38}$

\section{Views Regarding Polykinetics}

Several authors have discussed their views on the possible simultaneous nature of dance movement. In the Hungarian version of her paper, Szentpál adds a short discussion with regards to the "polyphony" of dance. ${ }^{39}$ From her perspective, if movements of a dancer's body parts are regarded individually as movement parts,${ }^{40}$ the dance is always "polyphonic." She introduces examples of one, two, and more parts: Figures 3 and 7 represent one part ${ }^{41}$ Figures 11-12 two parts, those of supporting legs and the arms clapping. She designates the movements on Figures 13-14 as multipart ones, both including movements of legs, arms, and the torso. Beyond mentioning the multipart nature of dance, she does not deal with the notion further on in her paper.

The so-called Syllabus, an early discussion on structural analysis by the Study Group for Folk Dance Terminology of the International Folk Music Council, con-

37. Without a preliminary posture of the body as a starting position, beat one can hardly be investigated as "transformation," because its representation as "change" cannot be defined.

38. Even if an analysis contains kinetography, the applied dialect needs to be identified. The two dialects, the European, usually called "Kinetography Laban," and the US-based system, called "Labanotation," may differ in certain significant points of reference, such as space hold or body hold, whether a body part carries along another one, or the calculation of rotations. The textual explanations of movement content in the cited papers could not be interpreted due to a lack of an established understanding of the meaning of the applied expressions.

39. Olga SZENTPÁL, "A magyar néptánc formai elemzése" [Form analysis of Hungarian traditional dance], Ethnographia 72/1 (1961), 5.

40. This refers to a "part" in polyphonic music. To distinguish between the understanding of the word "part" in a musical sense and as related to the body part (a section of a limb), its italicized version part is used in this paper, representing a sequence of movements running parallel with, and discussed independently from, other sequences.

41. Szentpál mentions only in the Hungarian version of her paper that the movements of paired body parts (arms and legs) are regarded as one part, even if their movements are different. See SZENTPÁL, "A magyar néptánc," 9 , footnote 20 . 


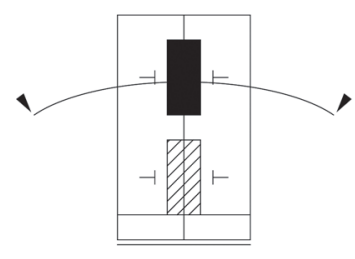

FIG. I I

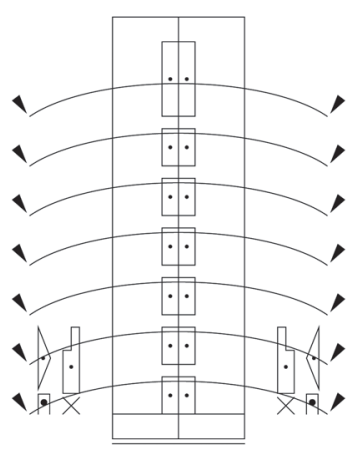

FIG. I 2

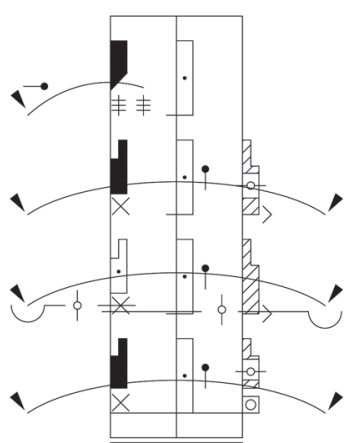

FIG. I 3

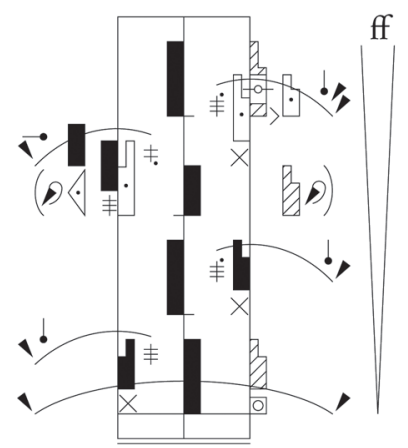

FIG. I 4

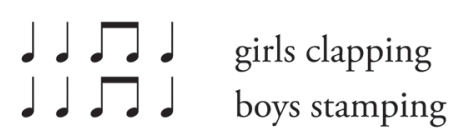

FIG. I 5

nects the term of polykinetics to the "element" which was "the result of an impulse process and can be simple (monokinetic) or complex (polykinetic)." ${ }^{42}$ In the advanced version of the Syllabus, Giurchescu and Kröschlova state that the "lines of patterned movements" could be "monokinetic" or "poly-kinetic," or formulated as "monoform or polyform." ${ }^{33}$ They explain that "poly-kinetic and/or poly-rhythmic units had two or more parallel running rhythmic and/or movement patterns," mentioning the Slovakian dance mak, where each step is delivered simultaneously with quarter-quarter-quarter-quarter rhythm hand claps. A further Slovakian example, the children's dance šijeme vrecja, is regarded as both "poly-kinetic and poly-rhythmic" when girls' clapping and boys' stamping were superimposed (see 
Figure 15). They consider the concept of lines of patterned movements a significant addition to the method of structural analysis:

It occurs in instances when synchronically executed movements in several parts of the body (legs, arms, hips, hands, and so on) or when several dancers are equally important and independent, thus building two or more parallel lines of patterned movements. ${ }^{44}$

The aforementioned investigation led by Van Zile explored the potential of movement analysis in dance research. ${ }^{45}$ To aid communication between expert participants, representatives of Labanotation and Effort/Shape Theory needed to establish a hierarchy of terminology relating to choreographic units, from the smallest to the largest, in the process of analyzing and notating a dance from southwest India. They introduced the term "element/component" as the smallest unit, which they felt was comparable to Kaepler's "kineme." It could be a single effort, a foot position, or a hand movement. They agreed that the succeeding level was the "constellation/cluster," a group of elements executed simultaneously, such as the hand waving concurrently with the head turning. ${ }^{46}$ The elements and clusters themselves were not identified in the enclosed notation, which is regrettable as the score included several temporally overlapping, but rhythmically different, movements. However, the adaptation of the "kineme" concept and the explanation of the term "cluster" indicate that they were aware of polykinetics, and they, too, regarded it as simultaneous movements of different body parts.

Even if the polykinetic view of movement emerged in the works cited above, the concept remained only a perspective, without attempts to consider it in performed analyses. ${ }^{47}$ All the above-mentioned approaches understood polykinetics as simultaneous movements of different body parts (legs, arms, torso, head) or by different dancers. ${ }^{48}$ If two legs perform monorhythmic and simultaneous supporting and gesturing movements (for example in Figures 3, 8-9), they are not regarded as representatives of polykinetics, they are rather viewed as a monokinetic series constituting a higher structure of an organic element: the motif. Despite

44. Ibid., 27.

45. BARTENIEFF et al., "The Potential."

46. Ibid., 6.

47. Discussing the morpho-syncretic aspects of expressivity, Andrei Bucşan also discussed the strongly varied kinetic structure of Romanian dances as generally ruled by "heterokinetism" and "polykinetism." See Andrei BUCŞAN, Modes of Expression in Roumanian Folk Dance. Expressive Traits in Roumanian Folk Dance (Trondheim: Radet for folkemusikk og folkedans, Rff-sentre, 1999), 26. The terms, unfortunately, were not clearly defined, therefore his concept cannot be compared to others.

48. An exception is László Kürti, who understands the notion of polykinetics differently: not as synchronic but diachronic kinetic elements of a sequence. He states that a single step Labanotated in his paper consists of three kinetic elements, which form a higher polykinetic unit, called "cell." See László KÜRTI, "Hungarian Dance Structures: A Linguistic Approach," Journal for the Anthropological Study of Human Movement 1/1 (Spring 1980), 50. 
a detailed distinction between movements, the complex group of actions on the first beat of Figure 10 was understood by Williams as a single "gesture" from the perspective of action utterances. ${ }^{49}$

\section{Simultaneous Events}

A challenge when applying musicological or linguistic theories to establish the basic units of dance arises from the differences in physical characteristics of such entities. In simplistic terms, units of music or speech can be reduced to single, physically more or less "static" sound elements. By contrast, a unit of movement is a change. The inherent feature of a single movement is the spatial shift in which it is realized; a sequence of movements is a series of changes. Nonetheless, the element/kineme concept might be productive if another, more definitive and significant, difference between the realization of a single sound of music or speech and a single dance movement could not be recognized: a single movement by a body part or by the whole body may include several, expressively significant changes at the same time. A single, identifiable change, separable from other changes, is here termed an event of movement.

The examples below illustrating this discourse are notated from original traditional dance. ${ }^{50}$ The movement analysis - the distinction of events - is based on the analytical theory of the Laban kinetography. ${ }^{51}$ This approach investigates only the spatial change, but not the timing, of movements as a distinguishing factor.

In Figure $16,{ }^{52}$ the only expressive content of the two beats is the bending and stretching of the supporting legs (and, as a consequence, the dropping and elevating of the center of weight); no other change is noted..$^{53}$ Both supporting legs perform concordant movements in each rhythmical unit, and each quarter represents a single-event movement. In Figure 17, similar extension and flexion of the supporting legs (the elevating and dropping of the body) as in Figure 16 are completed with outward and inward rotations (firstly in the form of a heel click,

49. WILLIAMS, "Human Action Sign," 52.

50. Most of them were already published; their archive or publication references are provided in the Index of Motifs at the end of this article. A beat of a measure corresponds to a quarter, except if indicated otherwise and re-evaluated as eighths. The names of dances listed in the Index of Motifs convey information regarding the approximate tempo.

51. The dialect of the notation system applied here is that of Albrecht Knust and Mária Szentpál, with some added notions by the present author. See KNUST, Dictionary; Mária SZENTPÁL, Táncjelírás: Lábán kinetográfia [Dance notation: Kinetography Laban], 3 vols (Budapest: Népmüvelési Propaganda Iroda, [19761979]); János FÜGEDI, Tánc - Jel -Irás: A néptáncok lejegyzése Lábán-kinetográfiával: Szóló-és körformák (Budapest: L'Harmattan / MTA Zenetudományi Intézet, 2011); id., Basics of Laban Kinetography for Traditional Dancers (Budapest: Institute for Musicology RCH HAS, 2016).

52. Ivan IVANČAN, "Index von Tanzmotiven von Kolo-tänzen in Slawonien und Baranya," in Analyse und Klassifikation von Volkstänzen: Klassifikationsprobleme der europäischen Volkstänze mit besonderer Berücksichtigung der Reigen- und Solotänze, ed. by Grażyna DABROWSKA and Kurt PETERMANN (Krakow: Polskie Wydawnictwo Muzyczen, 1983), 61. 


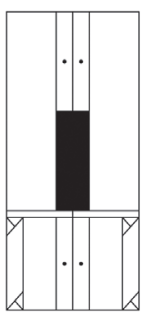

FIG. I6

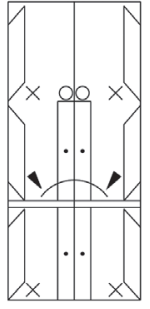

FIG. I7

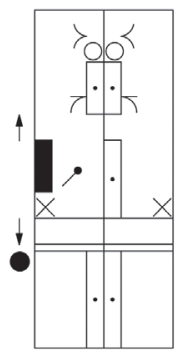

FIG. I 8

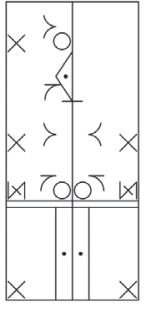

FIG. I9

the second as the preparation - if the sequence is repeated). The two, distinctly different movement concepts - extension or flexion (the change of level) and the rotation - are performed simultaneously; two independent events are presented on a rhythmical unit of a quarter as the supporting legs move in tandem. Independence of events means the possibility of performing one event without the other. A flexion or an extension is possible without rotation and vice versa; a rotation of the supporting leg can be presented without changing the level of support.

On the last eighth of Figure 18, both legs sustain their position, and the level of support remains unchanged as well. The only movement that can be observed is the supporting leg's roll from heel to whole foot: it is a single-event movement. On the first and second eighths of the main beat of Figure 19, two distinct events are performed simultaneously: the change of support level and a change of parts of the foot similar to that in Figure 18. Both movements comprise two simultaneous, expressive, and therefore significant, events. ${ }^{54}$

In the movement examples investigated above, the structure of the support (the legs in relation to each other), did not change. In Figure 20, parts of the foot and even the level of supports remain unchanged, ${ }^{55}$ yet the legs alter positions from

53. The harmonic cooperation of the participating three joints - the hip, knee, and ankle - is condensed into the notion of the leg's flexion and extension. The analysis here is not intended to comprehensively detail the movement anatomy. The focus is the expressive content of the movement, rather than the manner in which it was created physically and anatomically. If the body is supported on legs, the flexion and extension correspond to the change of support level. The two events with the same physical result are used here interchangeably.

54. Nancy Frishberg draws attention to simultaneously realized aspects of the American Sign Language, called "parameters," as implications for establishing a successful notational set for ASL. See Nancy FRISHBERG, "Writing Systems and Problems for Sign Language Notation," Journal for the Anthropological Study of Human Movement 2/4 (Autumn 1983), 171. However, her remark refers to static hand shapes accompanying a prescribed movement, and not to the process of changing shapes.

55. Types of springs according to the vertical change of the center of weight are discussed in my paper. See János FÜGEDI, “Springs in Traditional Dance: An Analysis and Classification,” Studia Musicologica 40/1-3 (1999), 185-187. Here I introduced a minor change in the system of indication. Formerly, the small arrow represented only the fact of the change of support levels and always pointed upwards. Reconstruction practice called attention to the upward-pointing arrows for different movement directions of the center of weight which confused recognition; therefore, now the direction of the arrow (pointing upwards or downwards) represents the direction of the change of support level. 


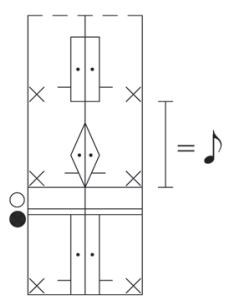

FIG. 20

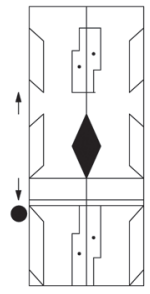

FIG. 2I

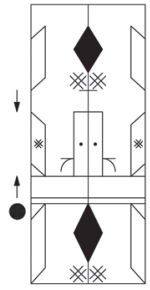

FIG. 22

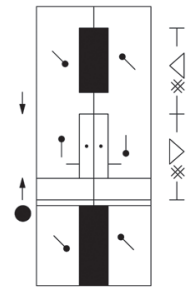

FIG. 23

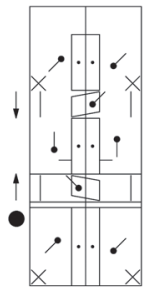

FIG. 24

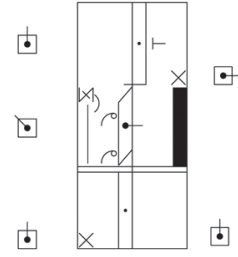

FIG. 25

first to second and return to first. The present analysis investigates the actual displacement of legs, which can be understood as the displacement of feet. ${ }^{56}$ In Figure 20, the content of consecutive movements is limited to the directional change alone; according to the view discussed here, the movements of supporting legs are single-event. In Figure 21, a further two, different, events accompany the displacements of feet: rotations of legs and the direct, undeviating change of the vertical level of the body. ${ }^{57}$ Figure 22 is even more complex: three changes (events), direction, level, and rotation are completed with alterations to parts of the foot.

Figure 23 adds a further type of event to those discussed: the whole body is traveling from its previous place to a new one: in the first beat to the right, in the second to the left. Figure 24 introduces a further new event: a turn around the vertical axis of the body. ${ }^{58}$ Simultaneously with the turn, the dancer changes the relation between the supporting legs, the level of support, and the parts of the foot in contact with the floor. Four simultaneous events are performed during a single rhythmic value of a quarter.

Figure 25 represents an exceptional correlation of simultaneous events. In the first beat, the dancer turns to the right, elevates her body from a low-

56. From this respect, attention is called to Kaepler's approach, which is different from the movement analytical concept of kinetography. Kaepler subdivides her step kinemes L1, L2, L3 into "regular" and "place." See KAEPLER, "Method (1972)," 178. (She distinguishes L1 as forward and L2 as backward, but L3, which represents any sideward step, is not distinguished by the left or right direction. This interpretation binds the side of the body to a direction, that is, no kineme can describe a crossing step, e.g. a step to the left with the right leg.) Kaepler's republished paper with Labanotation highlights that her view does not distinguish between taking support and making contact with the floor; that is, a contact with the right leg is identified as kineme L3b as a step by the same leg to the same place. See KAEPLER, "Method (2007)," 79. The main movement analytical (and implicitly, structural and expressive) difference is that in the case of a contact there is no transference of weight from one leg to the other, while a step represents a complete transference of weight. Consequently, Kaepler's view supports the same "kinematic" way as gestures when she takes into consideration the direction of motion, that is, the vector of the moving body part. In this respect, she follows Laban's notation concept published in Choreographie (see, for example, LABAN, Choreographie, 50-53). Laban abandoned this approach when kinetography was developed.

57. The importance of the change of vertical level was stressed several times, primarily by Norwegian ethnochoreologists Egil Bakka and Jan-Petter Bloom. See Egil BAKKA, "Analysis of Traditional Dance in Norway and the Nordic Countries," in KAEPLER and DUNIN (eds.), Dance Structures, 108; Jan-Petter BLOM, "Structure and Meaning in a Norwegian Couple Dance," Studia Musicologica 33/1-4 (1991), 423.

58. A turn may be regarded a movement concept similar to limb rotation, now related to the whole body. 
er level of support, and in synch with these two events on the first quarter, she performs two eighth-rhythm heel drops. During a pair of simultaneous events (turn and elevation), a third is presented twice; all three are performed by one supporting leg. Beyond its attraction, the composition is exceptional: the staccato, downward directed heel drops are small, but vertically opposite movements of the continuous elevation. Apart from aesthetics, no linguistic model can reflect the intricate inner structure of this multilayered complexity of movement events. ${ }^{59}$

The discussed events are all distinct. Each can be performed alone, as a single, significant movement of expression, or in combination in the flow of dance, and always possessing definitive rhythmic value. The events cannot be defined as "allokines:" 60 their presence is intentional, expressive, and dependent upon the decision of the dancer. The events presented are representations of abstract spatial concepts, performed individually or simultaneously.

The simultaneity of events, especially when they contain different rhythms and are synchronous (see Figure 25), challenge the general validity of linguistics-based dance analysis. ${ }^{61}$ A dilemma that stems from disregarding the complexity of simultaneous movement events is demonstrated in Martin's first attempt to classify motifs of a legényes dancer to the analogy of dictionaries. ${ }^{62}$ Similarly to word families, Martin establishes motif families based on motif starting cells, ${ }^{63}$ which include two or three "members." He states that the first five motif families begin with leg gestures and the second movement is usually a small spring from one leg to the same. ${ }^{64}$ Surprisingly, the cell of class 1 is introduced as in Figure 26: the determinative first movement is a step with rotations, and a change of support follows instead of repeated support. Members of class 1.2.1 are presented as in Figures 27 and $28 .{ }^{65}$ Martin confronted the challenge of how to classify movements including equivalent simultaneous events: the change of single supports should have belonged to class 11 as declared by its cell (repeated here in

59. Even if a heel drop can be isolated as a movement of the ankle, the elevation of the body (the extension of supporting legs) involves all three joints: the hip, the knee, and the ankle.

60. A relatively insignificant particle of meaning (see BIRDWHISTELL, Introduction, 6), or "variations, which do not change differential meaning" (ibid., Addendum). Here, it can be understood as a change that does not influence the movement content significantly.

61. The notion of simultaneous events is distinct from another linguistic concept, the suprasegmentals of phonemes as proposed by Jakobson and Halle. See Roman JAKOBSON and Morris HALLE, "Phonology in Relation to Phonetics," in Manual of Phonetics, ed. by Bertil MALMBERG (Amsterdam: North-Holland, 1968), 411-449. A component of different simultaneous events can be performed alone and can constitute the movement itself, or the movement can be composed of several equivalent events simultaneously. A suprasegmental is not an independent, distinct segment.

62. KARSAI and MARTIN, Lörincréve.

63. Originally, Martin used the term "motif root." The notion of "root" is borrowed from linguistics, where it refers to the most basic meaning of a word (see ibid., 81). The term was first introduced in his book on motif classification in the sense of "morpheme." See MARTIN, Motívumkutatás, 72.

64. KARSAI and MARTIN, Lörincréve, 76.

65. Ibid., 82 . 


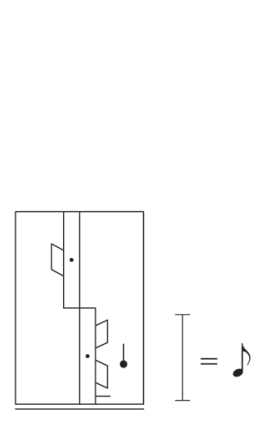

FIG. 26

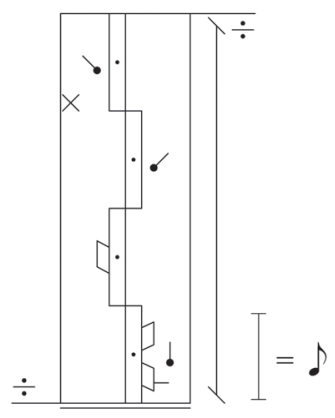

FIG. 27

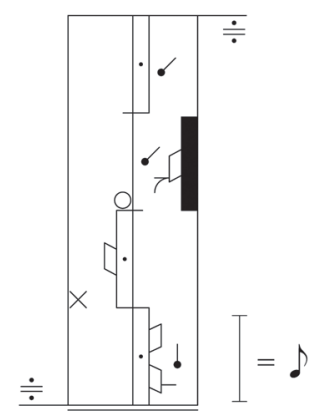

FIG. 28

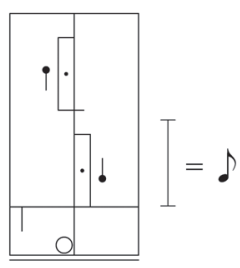

FIG. 29

Figure 29), while the rotation, which is a gesture, to class 1. Martin's limitation of two simultaneous events to one in order to satisfy the needs of a linguistics-based classification resulted in a contradiction in his system. ${ }^{66}$

\section{An Extension of the Polykinetic View}

To apply the aforementioned concept of simultaneous events to an analytical theory of content, an extension of the previously discussed views relating to polykinesis is necessary. The previously-cited authors indicated - Szentpál directly, and others indirectly - that they consider simultaneous movements of the supporting and the gesturing leg a unit. See, for example, both beats of Figure 30a, a pattern existing in a large number of varieties in several East Central European dances. Contrary to this practice, I propose to analyze the simultaneous movements of the supporting and the gesturing leg separately, and consider them different parts, because their movement contents are different. The supporting left leg repeatedly performs small springs on the same spot; if the motif is reduced to Figure $30 \mathrm{~b}$, where the leg gesture is missing, it cannot be taken as possessing significant expressive content. The expressive potential of the motif, however, is retained even if the accompanying supporting leg movements are missing, as shown in Figure 30c. Accordingly, actions of the gesturing leg represent the main kinetic content in Figure 30a; the consecutive gestures constitute the principal kinetic part of the two-part polykinetic dance. The identically repeated and simple small springs may be taken as the secondary part of the composition - though, without them,

66. Beyond the dilemma discussed, Martin's decision represents another theoretical change in his attitude towards analysis. With this step towards classification, Martin departed from his earlier position that the main principle of motif classification was the support structure, and he thereby shifted towards a vector approach. 


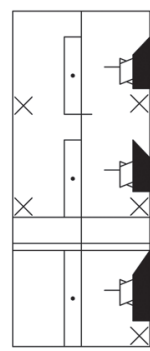

FIG. 3OA

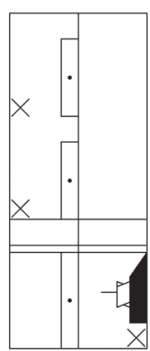

FIG. 3OB

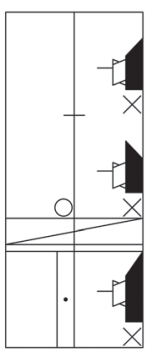

FIG. 3OC

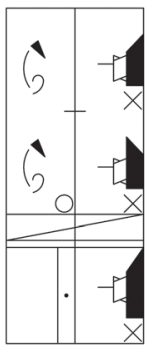

FIG. 3OD

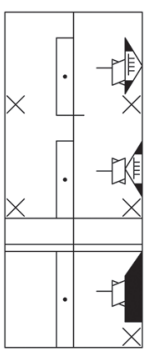

FIG. 3OE

the dance would look simpler and less impressive. If the part of the supporting leg was reduced to retaining the support with small vertical pulsations (as indicated in Figure 30d), the expressivity of the motif would not be significantly impacted; however, the lack of the gestural part would markedly decrease its former visual effect.

It can also be concluded from the above analysis that movements of the two legs may be worth investigating as separate, individual parts, even if double support is utilized. A difference of direction in the dislocation (that of the actual movement content) can be discovered, such as in Figures 20-21. The dancer arrives in the same second position on the first beats of these examples; however, the feet follow different paths because they begin from different positions.

\section{Spatial Oppositions as Themes}

The approach of separating the movements of supporting and gesturing legs, and considering the separated parts as containing expressive content, facilitates the recognition that different contents may formulate different themes, independent from each other. ${ }^{67}$ A theme of the gesturing leg can be observed in Figure 30a. The leg, especially its extremity (the foot), follows opposite paths to and fro, between the endpoints of the indicated forward diagonals. Figure $30 e$ represents the

67. The term theme is introduced, for lack of a better expression, to differentiate it from other usages such as motif-cell (cf. GIURCHESCU and KRÖSCHLOVA, "Theory," 29) or morphokine (cf. KAEPLER, "Method [1972]," 174) as it has independent, recognizable, and recurring content. Giurchescu uses the same term but, it seems, interchangeably with the expressions "motif" and "phrase." See Anca GIURCHESCU, "The Process of Improvisation in Folk Dance," in Dance Studies 7, ed. by Roderyk LANGE (Jersey: Centre for Dance Studies, 1983), 33. Here the term is detached from the understanding of motif, especially because - as it will be discussed in the following sections - a motif may include different parallel running themes. It should also be noted that musicology applies the term theme differently, referring to longer musical phrases. See William DRABKIN, "Theme," Grove Music Online (2001), <doi.org/10.1093/gmo/9781561592630.article.27789> (accessed 15 September 2018). 
dislocations with a different notation, which visualizes the oppositional left and right motion of the foot. ${ }^{68}$

Another type of opposition can be detected in Figure 31. It is evident that the gesturing leg again possesses the principal part; stamping in quarter-quartereighth-eighth-quarter rhythm, it changes rotation outward and inward (to parallel), accompanied by the small, downward accented pulsations of the supporting leg. As gestures in Figures 30a-c represent directional opposition, the theme of toand-fro rotation can be considered rotational opposition. The two oppositions performed by the same gesturing leg, the directional and rotational, frequently appear together as parallel themes of simultaneous events; see, for example, Figure 32.

Another type of opposition can be observed in Figure 33: the usage of oppositional edges of the foot, the heel and the tips of the toes. In this rare occurrence, the dancer applied the opposite parts of the foot without directional displacements or rotations.

Figure 34 includes all three spatial oppositions discussed above as performed simultaneously: the directional, the rotational, and that which is represented by the parts of the foot. With regard to variation, each movement of the gesturing leg possesses three simultaneous events: change of direction, rotation, and parts of the foot initiating contact. The successive events formulate three parallel running themes, each of which represents different spatial oppositions. Each theme can be performed alone (Figures 30-31, 33), in a combination of two (Figure 32), or all three can run parallel (Figure 34). The content of complex movements becomes increasingly richer, the level of expressivity is enhanced, and the performance requires accumulative skill as the number of parallel running themes proliferate.

\section{The Concept of Contrakinesis ${ }^{69}$}

In the above examples, the gesturing leg's specific usage of space can be conceptualized as contrakinesis. A pair of movements is contrakinetic if it represents immediate, successive spatial opposition. Movement events are members of the contrakinetic pair only if they possess definitive, distinct rhythmical values.

68. The notation method is called DBP (Direction-from-Body-Part indications). See Ann HUTCHINSON GUEST and Joukje KOLFF, Floorwork, Basic Acrobatics (London: Dance Books, 2003), 42-57. The use of DBP highlights the theoretical difference between the notation of support and gesture movements in kinetography. For most support movements, kinetography applies the motion analysis, that is, it denotes the actual direction ("vector") of displacement. However, for most gestural movements, the destination analysis (the definition of the arrival points of limbs) is used. In DBP, gesturing displacements are viewed as "vectors;" when the movement content is explained, the motion analysis is taken into consideration.

69. The theory was first presented by myself at the 2006 symposium of the ICTM Study Group on Ethnochoreology in Cluj. See János FÜGEDI, "Motivic Microstructures and Movement Concepts of Expression in Traditional Dances," in From Field to Text \& Dance and Space: Proceedings of the 24th Symposium of the ICTM Study Group on Ethnochoreology, ed. by Elsie Ivancich DUNIN, Anca GUIRCHESCU and Csilla KÖNCZEI (Cluj-Napoca: ISPMN / ICTM, 2012), 43-46. 


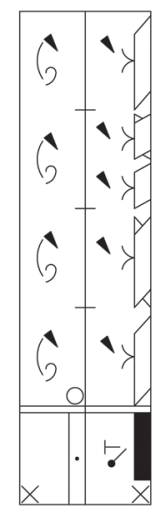

FIG. 3 I

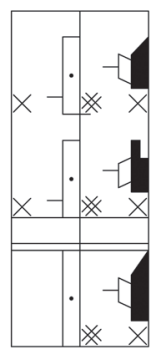

FIG. 32

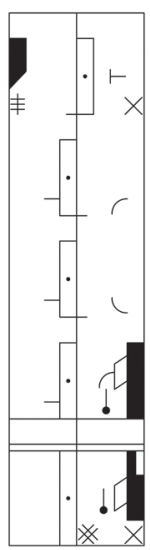

FIG. 33

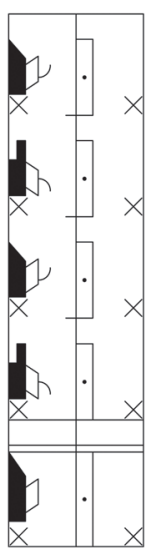

FIG. 34

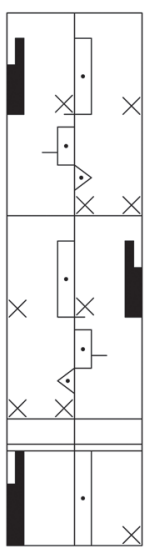

FIG. 35

The immediate successive spatial opposition is a determining characteristic of movement pairs considered contrakinetic. For example, the symmetrical repetition of the so-called three-step motif, a frequent pattern in traditional dance (a variation of which is shown in Figure 35), is not an example of contrakinesis. The differentiation between concepts is fundamental analytically. Contrakinesis is a principle of creation through which to elaborate a movement pattern or motif. A certain analogy, ${ }^{70}$ as demonstrated in Figure 35, corresponds to a repetition of an already produced movement sequence; repeating a "ready-made" pattern is a matter of formulating complex entities of dance.

Simple but characteristic contrakinetic structures performed by consecutive leg gestures are demonstrated in the following examples (all of which are motifs from Hungarian traditional dance). In Figure 36a, in an eighth-eighth rhythm section of a pattern, the gesturing left leg opens to the side low, before contacting the floor forward. The directional opposition is completed with the parallel running contrakinetic rotations of the same leg. In the accompanying part performed by the supporting leg, the small springs include contrakinetic rotations, which happen to be oppositional to those of the gesturing leg. This opposition is not contrakinetic, as contrakinesis can only be formed by consecutive movements of the same body part. It is notable, however, that opposite rotations of the gesturing and supporting leg enlarge the visual effect of synchronous movements. The metrical relation of the lateral symmetrically repeated, eighth-eighth rhythm pair is illustrated in Figure 36b, as performed in the dance. Figure $36 \mathrm{~b}$ is represented differently in $36 c$, beginning with the second eighth, to aid recognition of the sim-

70. Such as identical, lateral symmetrical, sagittal symmetrical, oppositional, and so forth. See HUTCHINSON GUEST, Labanotation, 303-318. 


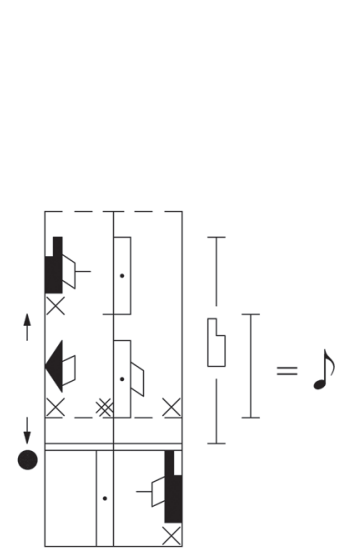

FIG. 36A

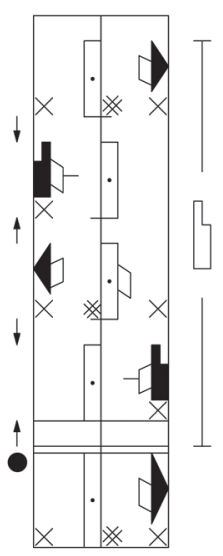

FIG. 36B

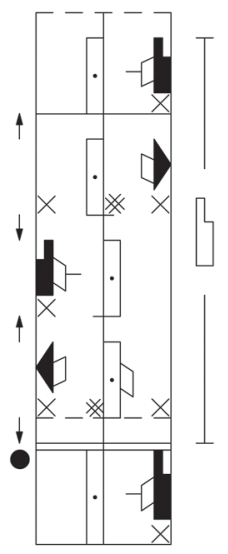

FIG. 36C

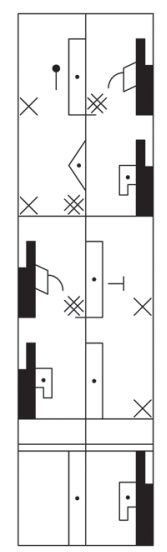

FIG. 37

ilar contrakinetic concept in Figure 37. Here, instead of sideways, a backwardforward opposition of gesturing leg movements is performed.

Figure 38 can be considered a completed variation of $36 a$. The sideward opening-closing gesture is continued with rotational oppositions only. The right leg maintains its direction during beats two and three; only its rotation is changed whilst repeatedly contacting the floor. Note the role of the supporting leg as it accompanies gestures. Its consecutive rotations now match those of the gesturing leg; however, while the rotations are contrakinetic, their directional accordance with the rotations of gestures strongly alters the expressive content of the complex movement sequence.

Aside from a metrical quarter shift, Figures 39-40 show similarities conceptually. The theme of continuously changing rotations of the gesturing leg is initiated in eighth-eighth-quarter rhythm, even though the theme of rotation in Figure 39 is initiated with an inward, and in 40 with an outward, rotation. ${ }^{71}$ The quarter augmentation in rhythm interrupts the continuous dichotomy of changing rotations. These sequences can be regarded as examples of incomplete contrakinesis. While the similarities of spatial patterns between Figures 37 and 38, as well as between 39 and 40, are apparent, the compared sequences derive from locales upwards of a thousand kilometers apart. Incidental similarities cannot be a result of simply imitating each other, they rather result from adopting the same spatial concept.

71. The notation in Figure 40 represents rotation explicitly only when the rotation symbol is attached to a place low direction sign. Rotations of the gesturing leg can be recognized from the separated directions of the thigh and the lower leg. 
Figure 41 represents two different contrakinetic themes performed consecutively (and subsequently repeated in this combination symmetrically). Changing the side of the body to support on the left leg once departing from the starting position, the dancer crosses the right lower leg behind the supporting leg to middle level; on the next eighth with an opposite, lowering gesture, he hits the other leg with the foot from behind. The second contrakinetic theme is similar to that of Figure 36a, a "Charleston"-esque pair in the gesturing leg. Note that the movement part of the supporting leg is reduced to a secondary, here also accompanying, role of small springs in the same place.

Beyond leg gestures, contrakinetic correspondence of supporting movements can also be found abundantly in Hungarian traditional dance; Figures 20-24 have already illustrated examples. One simple instance is Figure 20: the feet open into a second and close into a first position. Figure 21 represents a more sophisticated contrakinesis; the diachronic performance of three simultaneous events comprises three parallel running contrakinetic themes. The change of location of the feet, from a fourth position to a second and a return to fourth, is contrakinetic from the perspective of horizontal dislocations: from the starting position, the left foot changes its place diagonally backward, the right diagonally forward in the first beat; the second beat is the spatial opposition of the first. The change of leg rotations inward and outward are also contrakinetic; and the down-up movement of the center of weight, the body as a whole, is vertically contrakinetic.

Figure 22 features the same three concepts of contrakinetic themes as those discussed above, except the directional change of feet is sideways instead of diagonal. The added change of parts of the foot cannot be defined as contrakinesis, as it does not involve genuine opposition. However, the change from low heel to the whole foot is definitively a contrast between the surfaces of the supporting foot, and it represents a fourth parallel running theme.

In Figure 23, the change of position and the vertical level of the body are the same in relation to contrakinesis, as in the previous example. A new type of opposition can be discovered in the to-and-fro displacement of the whole body; therefore, three contrakinetic themes are performed simultaneously. The two contrakinetic themes embodied in the change of vertical levels and positions in Figure 24 are completed with the opposition of directions of turns.

Changes of single support can represent contrakinetic themes as well. In Figure 42, the left leg's forward step on the main beat is followed by a sliding spring backward in the second beat. The dancer rotates his supporting leg inward and outward in Figure 43; the alternating change of toe and heel drop results in a progression to the left. The contrakinetic themes of support are completed with leg gestures. Note the high complexity of this small, eighth-eighth rhythm section of a legényes dance: three parallel running contrakinetic themes of the gesturing leg (change of direction, rotation, and the part of the foot) are accompanied by 


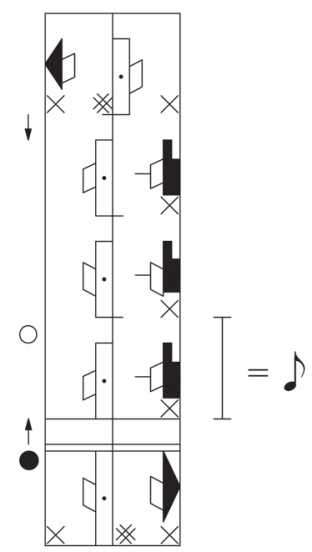

FIG. 38

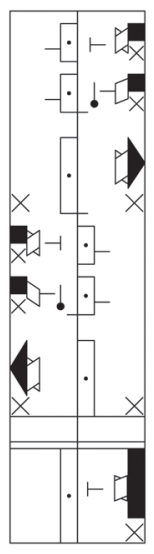

FIG. 39

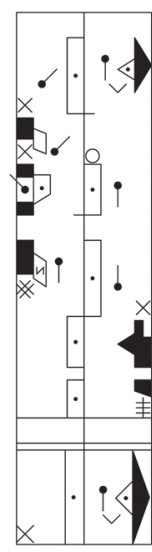

FIG. 40

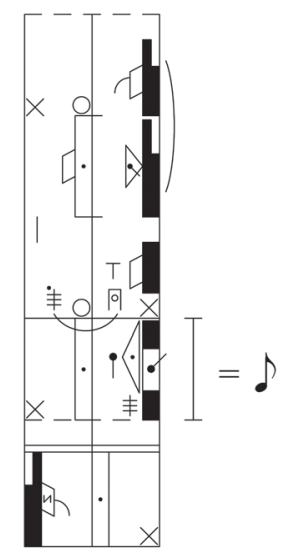

FIG. 4I

two themes of the supporting leg (change of toe and heel drops and contrakinetic rotations).

Split contrakinesis between movements of supporting and gesturing legs formulate a movement pair in Figure 44, which resembles the content of Figure 20 direction-wise; the feet open sideward into a second position on the floor, and close as they meet each other in the air. The similarity of the dislocation's directions is evident, even if the second member of the pair cannot be maintained as it is in the air. The opposition of vertical up and down is an added content compared to Figure 20, where the level is retained unchanged.

A transfer of contrakinetic themes between gesturing and supporting movements can be discovered in Figure 45. The sequence is initiated with a movement pair of the gesturing left leg, presenting the parallel running oppositional themes of opening-closing and rotating inward and outward, while the supporting leg adds the secondary part of small springs, which formulates a theme of the center of weight moving vertically down and up. The next pair of supporting movements repeats all the previous themes as the supporting legs open and close, rotate inward and outward, and the body continues its down-up pair of changing levels.

A masterpiece of interplay with the contrakinetic concept, and at the same time a manifestation of the creative craft of traditional dancers, is found in Figure 46. The two measures are seemingly simple. Note, however, the mirror symmetry of two parallel running themes. In the first measure, the eighth-eighth-eighth rhythm events of rotations formulate an inward-outward-inward theme, which is mirrored as outward-inward-outward rotations in the second measure. The feet follow opening-closing-opening paths in the first measure, which is mirrored in the second as a closing-opening-closing sequence. Echoing the two parallel themes divided by eighth-rhythm retentions of support is inherently demanding, 


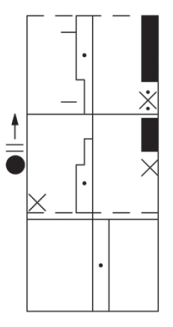

FIG. 42

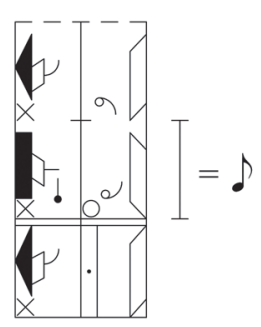

FIG. 43

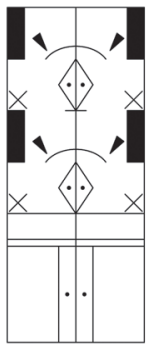

FIG. 44

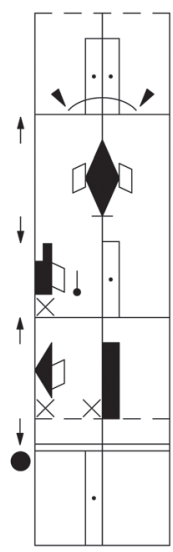

FIG. 45

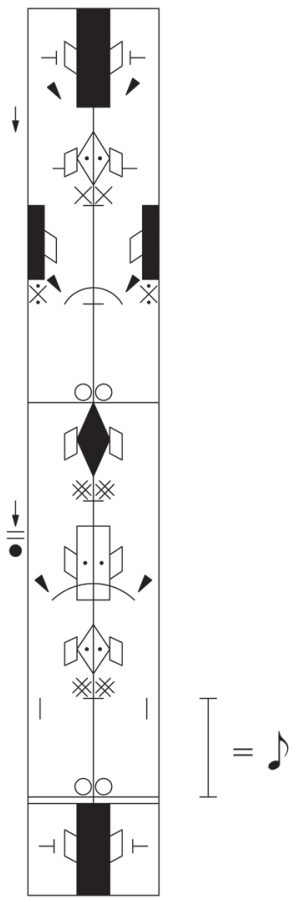

FIG. 46

and is further complicated by the asymmetry of the support structure and the vertical displacement of the center of gravity. Low support levels close both measures, but a high spring in the second measure replaces the maintained support in the first one. Understanding and reconstructing the sequence require a developed level of body consciousness.

Investigating how the contrakinetic pairs, with or without simultaneous events, are applied in traditional dance to build larger, repeated units comprising complex sequences (which former research regarded motifs) could be a subject of another discussion. Here only the concept is introduced as a frequently applied "method" of creating corresponding movement pairs in Hungarian, but in a wider sense, East Central European, traditional dance.

\section{Concepts of Contrast and Opposition in Traditional Dance Research}

The following discussion compares the contrakinetic theory and former interpretations of contrast and opposition concerning dance movements. John Blacking lists dichotomous elements of two dances of Vendas, such as denotative versus 
subliminal, mimetic versus abstract, cognitive versus affective, and functionally magic/social versus ecstatic/personal. ${ }^{72}$ Bucşan observes the contrast of the simple movements by women to figures of virtuosity performed by the man in the turning-wheeling couple dance învârtita. ${ }^{73}$

The research team lead by Van Zile found a variety of ways in which oppositions were achieved in the dance segment they analyzed, identifying the subject of their investigation "a dance of contrasts with an extremely high level of orchestration between multifaceted components." ${ }^{.74}$ Concerning spatial aspects, they note the soft flowing upper body movements versus rhythmic stamping by the feet, large sweeping movements versus small intricate gestures, and the oppositional interplay of hands. However, contrakinesis (spatial opposition) in the definition introduced above is not discussed in the paper, neither is it detected in the notation of the investigated dance, aside from a single, short occurrence: the shifting of the head to the right and left.

While discussing the creation principles of the ritual dance borica, Könczei concludes that "the system of 'borica' dance motifs is based on the coherent structure, its principle being the opposition." 75 Two of the transformation rules mentioned concern space as oppositional pairs: right and left, and forward and backward. However, the right-left opposition refers to which leg, the right or the left, commences a certain motif, or the leg instigating the motif moves forward and backward. The other two rules refer to stronger or lighter use of dynamics; therefore, they can rather be regarded as examples of contrast than those of opposition in terms of contrakinesis.

Zoltán Karácsony also mentions the principle of opposition in his analysis of legényes. ${ }^{76} \mathrm{He}$ describes the concept as a tool for the dancer "to return to the starting position of equilibrium." In Karácsony's view, the opposition is the lateral symmetrical repetition of a motif "the sideward process by a reversed motion," or compensation of a forward with a backward spring. The lateral symmetry is judged by Karácsony as a strong oppositional requirement, for, he declares, the dancer changed the customary rules of structuring the eight-measure section of legényes corresponding to a musical period. Again, such a notion of opposition is not a representation of contrakinesis, but - in a larger sense - that of a certain contrast.

None of the theories mentioned above investigated the movements in detail to recognize the immediate spatial oppositions of body parts. In the study most closely approaching the theory of contrakinesis, based on the corners of an ico-

72. John BLACKING, "Movement, Dance, Music, and the Venda Girls' Initiation Cycle," in Society and the Dance: The Social Anthropology of Process and Performance, ed. by Paul SPENCER (Cambridge: Cambridge University Press, 1985), 74.

73. BUCŞAN, Modes, 6.

74. BARTENIEFF et al., "The Potential," 9.

75. KÖNCZEI, "Principles of Creation," 118

76. Zoltán KARÁCSONY, "The Motifs of the Legényes of a Dancer from Bogártelke," in KAEPLER and DUNIN (eds.), Dance Structures, 177. 
sahedron envisaged enveloping the moving body, Laban discusses the oppositional directions of peripheral axis scales as a concept of space harmony ${ }^{77}$ Laban realized the expressive strength of immediate spatial oppositions; however, he applied them as whole-body movements, not as repetitive, individual movements of the same body part.

\section{Comparative Content Analysis}

The present comparative content analysis applies the aforementioned tools to discover the correspondence in, and between, contents of movement sequences that research has so far regarded as motifs. This analytical potential is exemplified by the further problem of systemized motif collections based on motif cells. As discussed above, the method developed by Martin classifies motifs according to the first movement, or movement pair, as a cell or root of the motif. ${ }^{78} \mathrm{He}$ regards the start of a motif the first movement that is performed on the main beat of a measure of the accompanying music. ${ }^{79}$ The cell, by which Martin distinguished his class 5 of legényes motifs, can be seen in Figure $47^{80}$ It is initiated with an aerial heel click on the main beat and is followed by the dancer's arrival at a single support. ${ }^{81}$ One of the members of this class is repeated here in Figure 48 (member 5.2.2.1.1). The movements of motifs in Figures 49-50 are identical with, or very similar to, the movements of Figure 48, and their sequence is the same as in Figure 48. However, the movement performed on the main beat is different in each case. In Figure 49 (a Romanian căluş motif published by Vera Proca Ciortea), the arrival on the single support after the areal heel click is performed on the main beat. ${ }^{82}$ In a sürü tempó motif in Figure 50, the contacting leg gesture corresponds with the main beat. Finally, the fourth shift of the sequence compared to the metric structure is shown in Figure 51, a Roma dance motif, where the second position is performed on the first beat of a measure. ${ }^{83}$

77. LABAN, Choreographie, 43-46.

78. KARSAI and MARTIN, Lörincréve; MARTIN, Mátyás István 'Mundruc'; KARÁCSONY, "The Motifs of the Legényes."

79. The relation of movement structures to the metrical system of the accompanying music is considered an important aspect of dance analysis. Martin and Pesovár state: "The structural analysis of the dances will necessarily yield a picture of the succession, the relationship of the major units, their connection with the musical units, of their temporal and kinetic relations. ... Our structural formulas will be based upon the musical units, this being the only way of representing satisfactorily the interrelation between dance and music." See MARTIN and PESOVÁR, "A Structural Analysis," 11.

80. Beat values in Figures 47-51 are eighths. It is indicated only in Figure 47.

81. MARTIN, Mátyás István 'Mundruc,' 282.

82. Vera PROCA CIORTEA, "The Căluş Custom in Rumania, Tradition - Change - Creativity," in Dance Studies 3, ed. by Roderyk LANGE (Jersey: Centre for Dance Studies, 1979), 19. The original publication does not include a re-evaluation of the beat. The accompanying music was notated in $2 / 4$, the dance in $4 / 4$. Here the music is followed for the rhythm of dance movements.

83. The unit of beats is an eighth for Figures 48-51; it is indicated only in Figure 47. 
In a system where classification of motifs is dependent on the relations of elements to the metrical system of the accompanying music (the main beat of a measure), similar sequences that begin contrastingly in this regard will be ranked into different classes. If the classification is restricted only to one person, and the dancer applies a certain sequence of movements only in one order, the classification may work. However, if the sample is wider, the classes may include a vast amount of redundancies. Conclusively, the relation of a sequence to the metrical structure is a characteristic, but not definitive, feature of the sequence's use. In a classification related exclusively to the metrical system of the accompanying music, establishing the thematically related motifs will be challenging, and identifying correspondences or differences of movement concepts in dance cultures can be lost.

In relation to contrakinesis, the content investigation of Figures 48-51 provides further conclusions. Structural similarities can only be investigated thoroughly if the contents of spatial relations (such as contrakinesis) are recognizably compared. It may become questionable which member of a contrakinetic pair forms the initial movement as a basis for comparison. Two contrakinetic movement pairs can be seen in Figures 52-53, out of context and apart from metrical

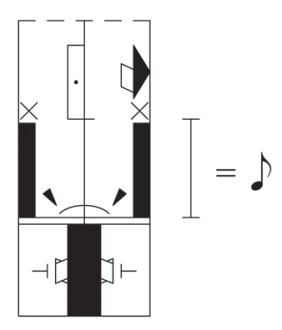

FIG. 47
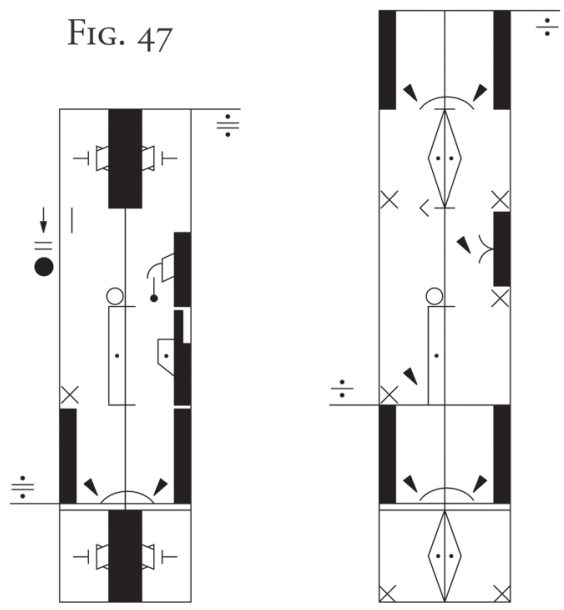

FIG. 48

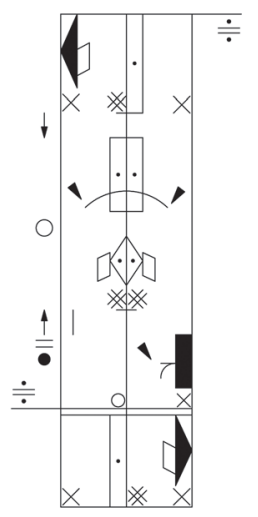

FIG. 50

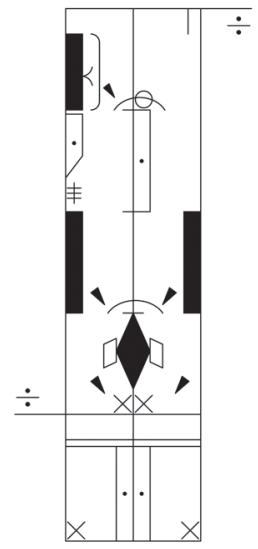

FIG. 5I 


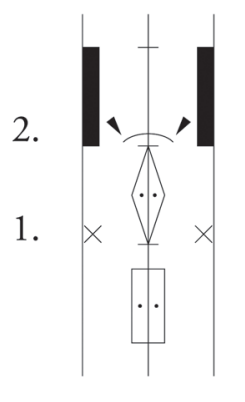

FIG. 52

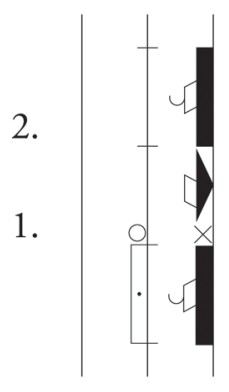

FIG. 53

relations. I propose that the member of a contrakinetic theme to be regarded as the first is that which opens or moves away from the center or the central vertical line of the body. Therefore, the second member is that which approaches the center of the body. Each movement with a distinct rhythmical value of the theme in Figure 52 has two events: dislocation of the foot sideward and a change of the level of the body vertically. The beginning movement of the theme dislocates the feet into open directions moving away from the center line of the body, and at the same time drops the body; the second dislocates the feet into directions closing toward the center line and elevates the body. The second unit of Figure 52, the areal state of the body also calls to attention that a contrakinetic theme does not have to conclude in maintainable support (cf. Figure 20).

In Figure 53, the content of the contrakinetic theme is significantly different. Contrakinesis is performed only by the gesturing leg, so the beginning and closing member can be defined by the dislocation of the gesturing leg. Therefore, the theme begins with the opening gesture (the right foot becomes farther from the center into a side direction) then it is closed with the returning (closing) gesture, which now concludes in a floor contact. ${ }^{84}$ It may be an aesthetical requirement of the parallel running rotation theme of leg gestures in East Central European traditional dance that inward rotations usually accompany sideward opening gestures, whereas outward ones are performed with gestures forward. The supporting leg is neutral from the perspective of contrakinesis. Its expressive role is secondary, though it may include some change of vertical level. Its function is usually reduced to facilitate the free leg to perform its part.

Independently from the above contexts, each theme can be presented in itself repeatedly as in Figures 44 and $33 a$, and each one in other combinations, as in Figures 41, 43, 45, and 46. As Figures 48-51 prove, their relation to the metrical structure of the accompanying music can vary within dance types or performances by different dancers. 


\section{Conclusions}

The complexities of East Central European traditional dance, the realization of simultaneity of different events by a single limb or by the whole body, and the synchronicity of appearing, disappearing, and re-emerging themes, may introduce a new perspective in dance analysis. The dilemma relating to motif classification demonstrates that the "motif-element" or the equivalent "kineme" concept may be valid either for dances containing only single-event movements, or for those regarded as discursive or mimetic. ${ }^{85}$ They may be applicable also to genres of movement systems in which each movement, no matter how complex, carries only one added meaning. The practice of reducing the abundant richness of the simultaneous events and parallel running themes of East Central European dance, their continuously evolving combinations, to simple and "unmeaningful" components of higher entities inhibits revealing the rich witticisms and creativity manifested in this tradition. On the one hand, without investigating simultaneous events and parallel running themes, dance analysis may lose the potential to discover unique expressivity. On the other hand, establishing the customary, fixed, or attached use of events and themes in the tradition of a community or individual practice may aid comprehension of similarities and differences of dance cultures, dialects, or individual creativity.

The independence of parallel running contrakinetic themes representing separate movement parts raises the challenge of whether it is possible to establish a coherent "dictionary" of motifs, even when focusing on a defined region such as Central Europe, or in such a narrow subject of dance research as a single dance type. Martin established six criteria which define a motif of traditional dance: a motif is 1) the smallest organic unit of dance; 2) a repetitive, returning unit; 3) a unit that can be recalled mentally or through skill; 4) a manifestation of elemental form creation; 5) an expressive unit of dance; and 6) the smallest unit that survives in a tradition. ${ }^{86}$ All six are just as valid for motifs as for recurring contrakinetic themes, of which the higher entities, the so-called "motifs," are built. Only one of Martin's considerations, the repetitiveness of units (number 2), is the objective trait that can be applied without theoretical assumptions; the remaining five leave a wide range of possibilities through which to draw diverse conclusions. ${ }^{87}$

The existence of simultaneous events and parallel running themes demonstrates that the classification of complex "motifs" is a much greater challenge than

85. BLACKING, "Movement," 71.

86. MARTIN, Motívumkutatás, 21-34.

87. In the process of establishing a coherent system of motifs, Könczei has raised the problem of a comparatively free interpretation by the researcher: "But the greatest difficulty was that in some cases we could not decide whether to consider some motifs as related to each other formally, or not. The most unpleasant was the realization of the fact that the decision was completely dependent on our will." KÖNCZEI, "Principles of Creation," 115. 
TABLE 1 Index of the Figures

The names of localities in brackets reflect today's borders. Abbreviations: IM RCH: Institute for Musicology, Research Center for the Humanities; Ft.: Film Collection of the Traditional Dance Archive, IM RCH; Tit.: Dance Notation Collection of the Traditional Dance Archive, IM RCH; Mot.: Motif Collection of the Traditional Dance Archive, IM RCH.

\begin{tabular}{|c|c|c|c|}
\hline $\begin{array}{l}\text { Figure } \\
\text { no. }\end{array}$ & Dance Name & Locality & Source \\
\hline 1. & férfi egyes tánc & Karcsa & Szentpál, "Versuch,” Fig. 18. \\
\hline 2. & csárdás & Kisterenye & Szentpál, “Versuch,” Fig. 20. \\
\hline 3. & kopogó & Mezőkomárom & Szentpál, “Versuch,” Fig. 1a; Ft.6. \\
\hline 4. & egyes verbunk & Majos & Szentpál, “Versuch,” Fig. 21; Ft.31. \\
\hline 5. & kopogó & Mezőkomárom & Szentpál, “Versuch,” Fig. 1b; Ft.6. \\
\hline 6. & egyes verbunk & Bodroghalom & Szentpál, “Versuch,” Fig. 36. \\
\hline 7. & karikázó & Sióagárd & Szentpál, “Versuch,” Fig. 25. \\
\hline 8. & verbunk & Simonfa & $\begin{array}{l}\text { Martin and Pesovár, "A Structural } \\
\text { Analysis," } 28 .\end{array}$ \\
\hline 9. & roveňačka & Přim Rychnov & $\begin{array}{l}\text { Giurchescu and Kröschlova, "Theory," } \\
42-43 .\end{array}$ \\
\hline 11. & egyes verbunk & Ricse & Szentpál, "Versuch,” Fig. 19. \\
\hline 12. & egyes verbunk & Kéty & Szentpál, “Versuch,” Fig. 27; Ft.30. \\
\hline 13. & kettes verbunk & Hidas & Szentpál, "Versuch,” Fig. 3a; Ft.30. \\
\hline 14. & egyes verbunk & Kisdorog & Szentpál, “Versuch,” Fig. 28; Ft.30. \\
\hline 16. & kolo & Presjekača & Ivančan, “Index,” 61, ex. 10. \\
\hline 17. & verbunk & Geszteréd & Ft.281.1; Tit.1241. \\
\hline 18. & friss csárdás & Bük & Ft.355.9; Tit.1105. \\
\hline 19. & karička & Pozdišovce & Ft.458.V.2; Tit.211. \\
\hline 20. & sürü magyar & Bonchida (Bonţida) & Ft.682.8; Tit.1360. \\
\hline 21. & friss csárdás & Decs & Ft.164.18; Tit.125. \\
\hline 22. & friss csárdás & Bogyiszló & ÁNE Ft.6.25; Mot.1654. \\
\hline 23. & cigánytánc & Polgár & Ft.327.19; Mot.3738. \\
\hline 24. & verbunk & Szamosszeg & Ft.383.5; Tit.58. \\
\hline 25. & cigánytánc & Nyírvasvári & Ft.322.14; Tit.35. \\
\hline 27. & pontozó & Lörincréve (Leorinţ) & Ft.224.8; Tit.1049. \\
\hline 28. & pontozó & Lőrincréve (Leorinţ) & Ft.625.15; Tit.1032. \\
\hline 30. & söprütánc & Mihályi & Ft.289.3; Tit.1436. \\
\hline 31. & barátoké verbunk & Jóka (Jelka) & Ft.1172.17; Tit.1317. \\
\hline 32. & kettes ugrós & Olad & Ft.36.13; Tit.1417. \\
\hline 33. & csárdás & Tyukod & Ft.640.5; Tit.1401. \\
\hline 34. & csárdás & Tyukod & Ft.640.5; Tit.1401. \\
\hline 35. & kanásztánc & Berzence & Ft.203.2a; Tit.820. \\
\hline 36. & zsibai & Lele (Lelei) & Ft.1056.2 \\
\hline
\end{tabular}


TABLE 1 (continued)

\begin{tabular}{|l|l|l|l|}
\hline 37. & legényes & Magyarvista (Viştea) & Ft.394.1; Tit.60. \\
\hline 38. & verbunk & Simonfa & Ft.223.7; Tit.1421. \\
\hline 39. & verbunk & Decs & Ft.164.1; Tit.72. \\
\hline 40. & verbunk & Méra & Ft.496.5; Tit.167. \\
\hline 41. & legényes & Bogártelke (Bagara) & Ft.637.1; Tit.1193. \\
\hline 44. & friss csárdás & Dávod & Ft.485.1; Mot.1928. \\
\hline 43. & legényes & Magyarvista (Viştea) & Ft.616.5a; Tit.1401. \\
\hline 44. & dus & Szany & Ft.759.5; Tit.876. \\
\hline 45. & ugrós & Alap & Ft.389.8 Tit.428. \\
\hline 46. & legényes & Inaktelke (Inucu) & Ft.541.3 Tit.199. \\
\hline 48. & legényes & Magyarvista (Viştea) & Ft.538.4; Tit.397. \\
\hline 49. & căluş & Pădureți & Proca Ciortea, “The Căluş," 19. \\
\hline 50. & sürü tempó & Szék (Sic) & Ft.671.27; Tit.1177. \\
\hline 51. & cigánytánc & Nyírlugos & Ft.230.4; Mot.17. \\
\hline
\end{tabular}

the same task relating to themes carrying synchronous and different contents. Therefore, motifs as sections of the dance composition, built from thematically manifold, rhythmically dual or triple small units (the latter is not investigated here), are highly complex. In their manner of composition, closed and elaborated "masterpieces" of creative minds, they are sometimes closer in expressivity to whole melodies or strophes of verses than lines of music or sentences, let alone "words."

Content analysis may shed light on the process of motif creation and may uncover spatial contexts, mechanisms of the creative "thinking" in traditional dance. The event-theme theory presented here is considered evidence that dance movements present forms of expressions that cannot be characterized by musicological or linguistic methods. It may invoke the need for an independent analytical path for dance - a path in its "own right" as Laban put it ${ }^{88}$ - since no other approach is viable in this regard. The exceptional potential for complexity in movement during a single rhythmical unit, the corresponding parts with their temporally parallel structures as discussed above, may also highlight the difficulties involved in cognizing non-discursive, expressive dance.

Without revealing the microstructures of traditional dance, the richness of inventions - unbound to established or acquired motif content - cannot be introduced. Overly simplified or improper representations of dance movements stunt the recognition of layers of expressions while, as discussed in detail above, especially in relation to movement concepts, exceptional complexity is evident. It is a fundamental and essential requirement to convey the complex content of the highly developed systems of movement demonstrated in East Central European 
traditional dance, and to find the appropriate analytical methods. In other words, the application of a reliable, valid notation system with clear analytical concepts that unambiguously communicate movement ideas is necessary. If dance research, beyond dealing with political, social, anthropological, or ethnological contexts, commits to focusing on the dance itself and its expressive, intrinsic aesthetics, there is no royal road. Choreology does not exist without dance literacy.

Open Access. This is an open-access article distributed under the terms of the Creative Commons Attribution 4.0 International License (https://creativecommons.org/licenses/by/4.0), which permits unrestricted use, distribution, and reproduction in any medium, provided the original author and source are credited, a link to the CC License is provided, and changes - if any - are indicated. 
